$i_{2} / i_{i}<0.3$ の場合:

$\left(i_{2}\right)_{\mathrm{corr} .}=-\frac{x}{1+x} i_{t}, \quad\left(i_{1}\right)_{\text {corr }}=i_{t}-\left(i_{2}\right)_{\text {corr }}$

$x<0.2$ の場合には $i_{2}$ の值が小さくなるので定量の精度が 減少 し，かつ次第に困難になる*1。

\section{3 セル抵抗の影響}

本法では 3 電極をもちいるために回路, セルの抵抗が大きい場 合でもその影響が少ない。この事実は DME のように電流の值 が変化しやすい場合に便利で, 本法は非水溶媒などセル抵抗の大 きい場合, 高浱度被還元物質の場合に利点を有していると考えら れ为。

$i R$ 降下の影響を調べるためセル抵抗を大きくする代りとして 加電流回路, 電位測定回路の陽極側にそれぞれいろいろの大きさ の抵抗を㨂入して電流電位曲線を記録した。表 4 にその結果を示 す。このさい, 電位差レコーダの高インピーダンス前置増幅器と

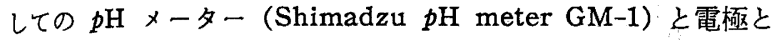
の接続はシールド線をもちいて行なった（電解セルおよび挿入し た抵抗は遮蔽せず)。このシールド線の使用は誘導の 影響をいち じるしく少なくして，2 M $\Omega$ の抵抗を挿入した場合でも半波電位 は $10 \mathrm{mV}$ 以内で抵抗を插入しない場合と一致した。（ただし，シ ールド線をるちいないと $100 \mathrm{k} \Omega$ の抵抗を 挿入した場合でも 10 $\mathrm{mV}$ 以上半波電位が变動する)。電流值に関してはマイクロアン
メータをもちいて測定すると挏入抵抗の影響はまったくなく，ま た実際のセル抵抗法大きくても数 $10 \mathrm{k} \Omega$ 以下であると考えると ボーラログラムの波高を測定しても誤差はほとんど無視できるこ とになる (加電流電源の直列抵抗は通常 $5 \mathrm{M} \Omega$ 以上である)。

このように本法ではセル抵抗の值を知らなくても電位，電流の 測定值に何ら補正を行なう必要はなく，完全な電流規正法になっ ている。著者は本法を $0.1 \mathrm{~N}$ 塩化りチウムを含むイソプロピル アルコール中の酸素波，四塩化炭素波などの測定に応用した。

\section{表 4 挿入抵抗の影響}

電解液組成 插入抵抗 $E_{i=1 / 2(i l)}$ $(\mathrm{k} \Omega) \quad(\mathrm{V}$ vs. SCE $) \quad(\mu \mathrm{A})$

\begin{tabular}{|c|c|c|}
\hline \multirow{4}{*}{$\begin{array}{l}1.00 \mathrm{mmol} / l \mathrm{~Pb}^{2+} \\
0.5 \mathrm{~N} \mathrm{HClO}_{4}, 2 \mathrm{mmol} / l \\
\mathrm{Cd}^{2+}, 0.01 \% \mathrm{PAA} \text { 中 } \\
\text { の } \mathrm{Pb} \text { 波 }\end{array}$} & $0.45_{0}{ }^{a)}$ & $-0.37_{7}$ \\
\hline & 20 & $-0.37_{b}$ \\
\hline & 100 & $-0.37_{7}$ \\
\hline & 500 & $-0.37_{8}$ \\
\hline & 2000 & $-0.38_{5}$ \\
\hline \multirow{3}{*}{$\begin{array}{l}1.00 \mathrm{~m} \mathrm{~mol} / l \mathrm{Zn}^{2+} \\
0.4 \mathrm{M} \mathrm{NH}, \mathrm{NH}_{4} \mathrm{Cl}, \\
0.01 \% \mathrm{PAA}_{\text {中の } \mathrm{Zn} \text { 波 }}\end{array}$} & $\left.0.45_{0}^{a}\right)$ & $-1.20_{4}$ \\
\hline & 500 & $-1.20_{6}$ \\
\hline & 2000 & $-1.21_{6}$ \\
\hline
\end{tabular}

注 $a) \mathrm{SCE}$ と供試液間の抵抗.

終りに本研究を行なうに当り終始御根切な御指導を睗りました 京都大学石橋雅義名誉教授，藤水太一郎教授に深謝致します。

\title{
電流規正ポーラログラフィーにおける異常現象*1
}

(昭和 36 年 3 月 8 日受理 )

$$
\text { 伊豆津公 佑† }
$$

電流規正ポーラログラフ法を用いて極大，極小現象，泳動電流，酸化電流，混液電位，反応電流，触媒電流，吸着波などのいく つかの例について検討した。本法では極大を生じないが波形がやや悪く，極小現象も異状な波形を示す。泳動電流，酸化電流，混 液丽位, 反応電流, 触媒電流, 财着波などは常法ポーラログラフ法とほぼ同様の加電流電位曲線が得られた。

\section{1 緒言}

滴下水銀電極 (DME) をもちいる電流規正ポーラログラフ法 では, DME の一滴の間, 加電流はほとんど一定であるが，電極 面積が時間とともに增大寸るために電流密度はきわめて大きい值 から速やかに減少する。その結果，たとえば被還元物質 $\mathrm{O}_{1}$ とそ の後放電物質とを含む電解液については, DME はその初期に後 放電物質の還元電位を示し，のち $\mathrm{O}_{1}$ の還元電位へと正向きに移 行する。このように後放電物質の還元がはじめに起きるために, $0_{1}$ の限界電流値が後放電物質の電極反応の影響を受けたり， あ るい後放電物質の還元型の再酸化に起因する小さい波を生ずる など常法ポーラログラフィーと異なる現象が起きることはよく知 られている1)。

本報では極大，極小現象，泳動電流，酸化電流，混液電位，反

*1 本報を “ポーラログラフ法に上万分析化学的研究 (第 40 報), 雨流規正ポー ラログラフィー（その6)”とする，前報，伊豆建，日化 82，1500 (1961)

$\dagger$ 京都大学理学部化学教室, 京都市左京区吉田本町

1) 石檑, 藤永, 伊豆禑, 日化 81, $1549(1960)$.
応電流, 触媒電流, 吸着波など常法ポーラログラフィーにおいて 特異的現象のおきるいくつかの例につき，電流規正法をもちいて 測定を行ない，常法と比較した結果を報告する。極大現象につい ては石橋, 藤永 ${ }^{2)}$ が電流規正ポーラログラフィーに関する最初の 報告で極大が現われないととを特徵の一つにあげており，その後 Kolthoff，沖中 ${ }^{3)}$ むかり詳細に検討している。

\section{2 装置および試蕌}

使用した装置は前報と同様である1。

DME の特性は $0.1 \mathrm{~N}$ 過塩素酸溶液中で $m=1.26_{0} \mathrm{mg} / \mathrm{sec}$, $t_{\max }=4.7_{0} \mathrm{sec}$ (開回路), $h=55.5 \mathrm{~cm}$ で, 実験は通常 $25^{\circ} \pm$ $0.1^{\circ} \mathrm{C}$ において行なった。

メチレンブルー, デキストロース, 硫化ナトリウム, 水酸化リ チウム，その他使用した試薬はすべて市販の特級品をそのままも ちい, 供試溶液を調製した。

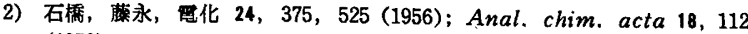
(1958).

3) I. M. Kolthoff, Y. Okinaka, J. Am. Chem. Soc. 80, 4452 (1958), 


\section{3 实釦結果および考察}

\section{1 柾大現象}

表面活性绪を含まない $0.01 \mathrm{~mol} / l$ 㙁化カリウム, 空気䬲和溶 液中の股素の第一波打よび $1.0 \mathrm{~mol} / l$ 塭化アンモニウムーアンモ

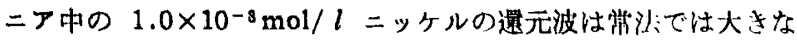
極大を生ずるが,本法では栖大がなく，限界電流值は常法の最大应 散電流とほほ $5 \%$ 以内で一致した（後放電物筫が不可逆選元》)。 しかし波高の再現性は極大抑制削を加光た場命より劣る。本法で は四 1 に示すように極大を生じないが，波形は良好なS字形でな く限界電流近傍の電位 $\left(E_{\max }\right)$ は異常に、な䉓位となる。した がって Kolthoff ら，8が鞎告したように極大抑制制を適当に加え ることが望ましい。

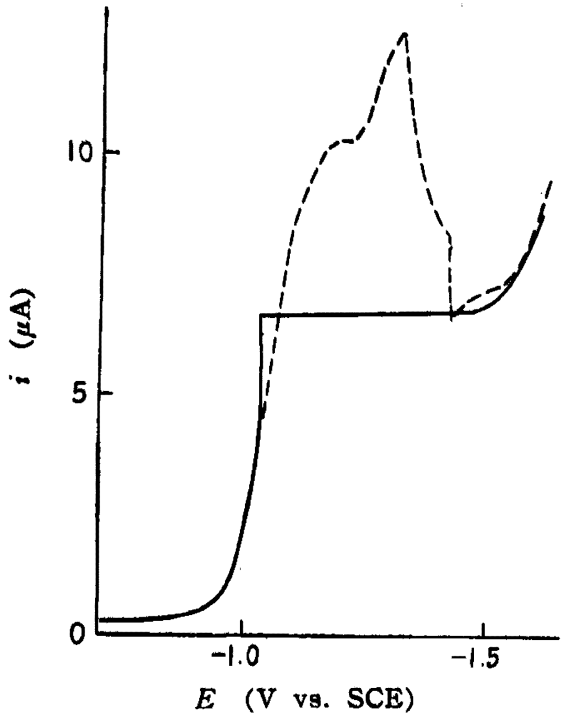

$1 \mathrm{~mol} / l$ 塩化アンモニウム $-1 \mathrm{~mol} / l$ アンモニア中の

$1.0 \mathrm{~m} \mathrm{~mol} / l$ ニッケルのポーラログラム

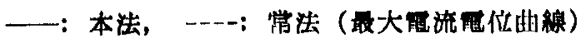

図 1 栖大現 象

\section{2 唒小珢}

因 2 に $0.4 \mathrm{~N}$ 硫酸， $1.0 \mathrm{~m} \mathrm{~mol} / l$ 銅， $0.005 \%$ Triton X-100 嘼液の銅波を示した。表面活性靔 Triton X-100 の添加によ? て銅の波形が極小を有する翼常な形になることは常法については 群細に検討されているい。常法で極小を尘ずる電位における電流 時間曲線は，表面活性刘の吸着速度とその電杨反芯の阻算の程度 により異なるがほほ汹2（a）のような形になるす。このため本法 における DME の電位㭙間曲線も椱雑になり，一定加電流で電

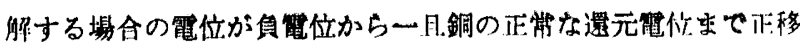
行してのた，ふたたび銅の不可逆還元の電位まで逆に会方闹へと 移行することがある(四2(b))。四 2 には $t_{\max }$ での電位 $E_{\max }$ を結えで得られる加電流電位曲線と，DME の一滴の閒でむつと む正な電什を結んで得られる曲線とを示した。

\section{3 泳勘流}

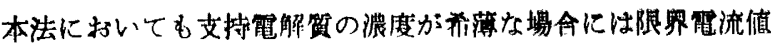

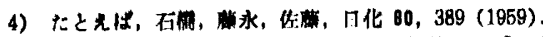

5) たとえば, R:W. Schmid, C. N. Reilley, J. Am. Chem, Soc. 80, 2087 (1958).

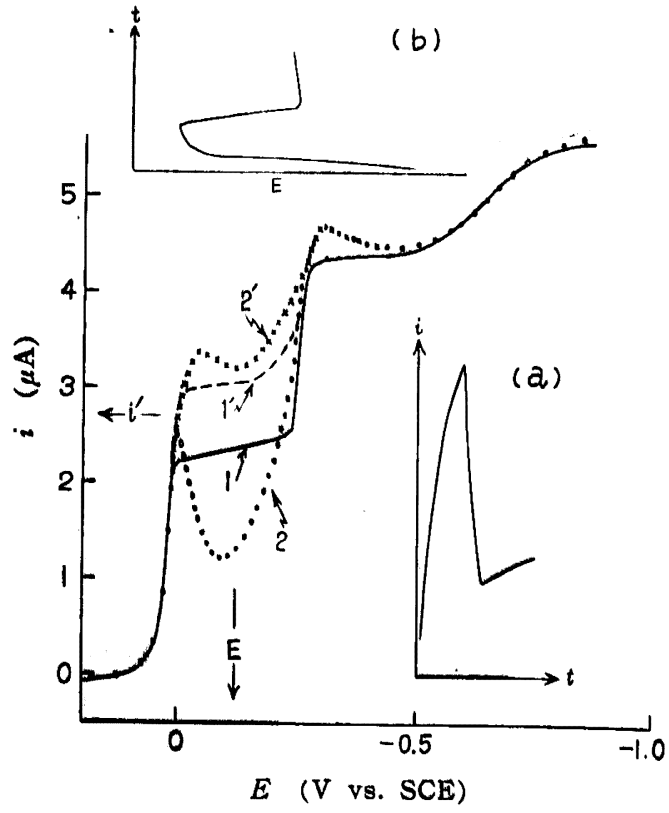

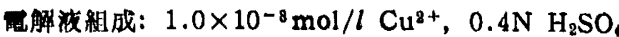
$0.005 \%$ Triton $\mathrm{X}-100$

1,1': 本法 2,2': 常法

1,2： $t_{\max }$ に打ける点を結んで得た坻流，两位曲線

$1^{\prime}, 2$ ': 扰の扰の 1 滴中もっとも正な两位扰よびもっとも

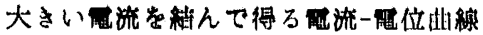

(a)：映位 $E^{\prime}$ 近傍の $i-t$ 曲線(常法)

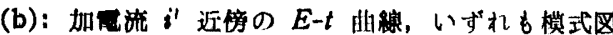

四 2 極小現象を生ずるポーラログラム

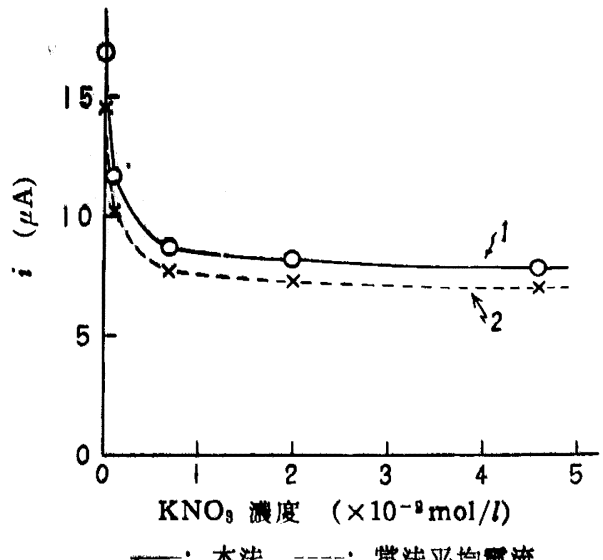

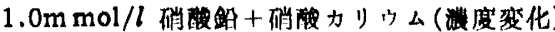

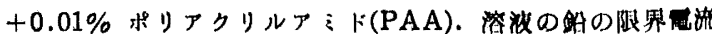

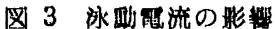

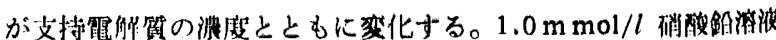

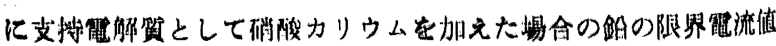

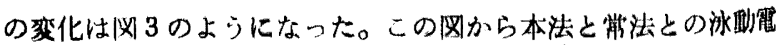
流の影毁はほとんど同じであると思われる。

\section{4 化流と湿洨西位}

$0.1 \mathrm{~N}$ 水酸化ナトリウム, $0.01 \% \mathrm{PAA}$ 中の硫戴イオンの酸化

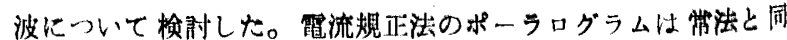

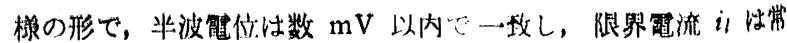
法の平均拡散笔流とほとんよ゙同じ仙i（3\% 以内で一致）を示し 


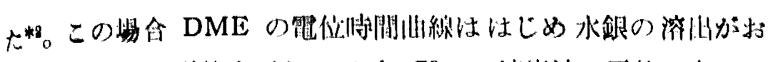

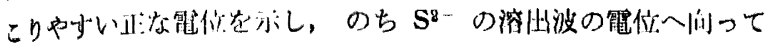
县方向に移行与\%。

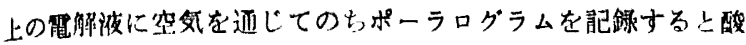

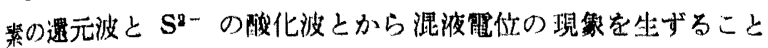

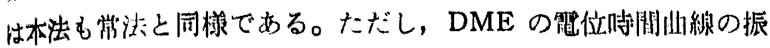

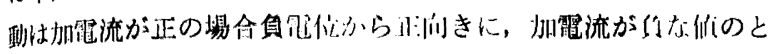

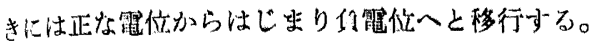

\section{5 反㤁流}

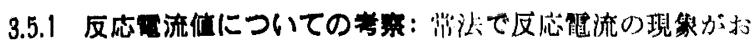

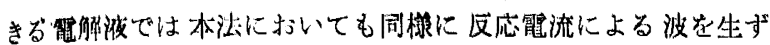
る。この波の限界筐流は常法について竞かれた結果をもちいてつ ぎのように冰められる。いま

$$
\mathrm{A} \underset{k_{2}}{\stackrel{k_{1}}{\longrightarrow}} \mathrm{O}_{1} \stackrel{n_{1} e}{\longrightarrow} \mathrm{R}_{1}, K=\frac{k_{2}}{k_{1}}>1
$$

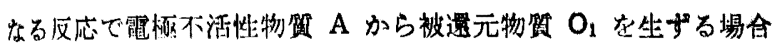

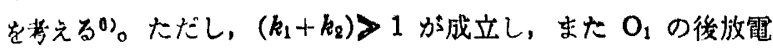
物貿 Os si十分多量存在与るとする。一定加電流 $i_{0}$ で電解を行

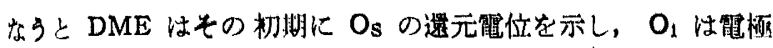

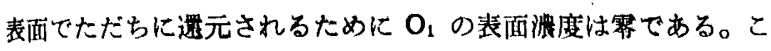
の埸合の $\mathrm{O}_{1}$ 0)反忘電流は Koutecky (7)，松田ら ${ }^{8)}$ に上って求め られて招り，松田旺によるとその電流 $i_{1}$ は，

$$
\frac{i_{1}(y)}{n_{1} F q}=D^{1 / 8} C^{*} \lambda-\lambda \int_{0}^{y} \overrightarrow{\sqrt{\pi(}(y-\xi)}\left[\frac{7}{3} \xi\right]^{-2 / 7} \frac{i_{1}(\xi)}{n_{1} F q} \mathrm{~d} \xi
$$

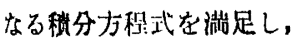

$$
i_{1}(t)=708 n_{1} D^{1 / 2} C^{*} m^{8 / 8} t^{1 / 6} \times\left\{\sqrt{\frac{3 \pi}{7}}(\lambda V t) \Psi(V t)\right\}
$$

で与竞られる。ここで $y=\frac{3}{7} t^{7 / 8}, C^{*}: \mathrm{A}$ および $\mathrm{O}_{1}$ の目液浱度 の和, $D: A, \mathrm{O}_{1}$ の拡散係数， $\lambda=\sqrt{k_{1}+k_{2}} / K$, 式 (2) の括弧 （）内の值は $\lambda V t$ の関数として表にされている日。

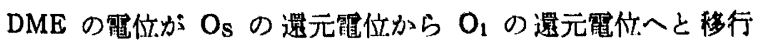

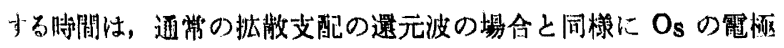
反応の可逆度により異なり，つぎのようになる。

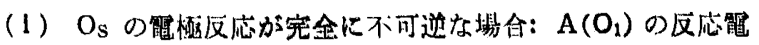

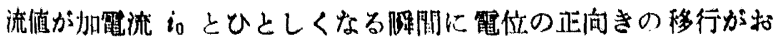

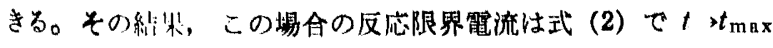
として,

$$
\begin{aligned}
i_{l}= & 708 n_{1} D^{1 / 2} C^{*} m^{2 / 8} t_{\max }^{1 / 8} \\
& \times\left\{\sqrt{3 \pi} 7 \cdot\left(\lambda \sqrt{t_{\max }}\right) \Psi\left(\lambda \sqrt{t_{\max }}\right)\right\}
\end{aligned}
$$

となる。

（11） $O_{\mathrm{s}}$ の電極反虑が可逆な場令： Os の還元型 $R_{\mathrm{s}}$ の電極

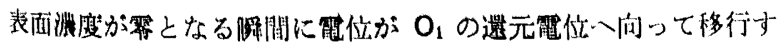

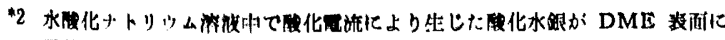

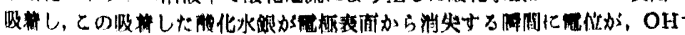

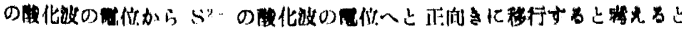

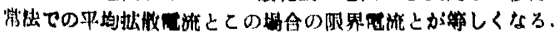

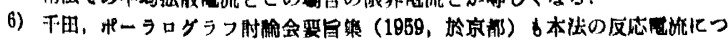

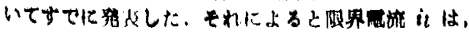
て表わきれる。

$$
i t=635 n_{1} D^{1 / 8} \mathrm{C}^{*} m^{2 / 3} t_{\text {max }}{ }^{1 / 0} \times \frac{1}{1+0.773\left(\lambda \sqrt{t_{\text {mux }}}\right)^{-1}}
$$

7) J. Koutecky, Collection Crechoslov, Chem. Communs, 18, 597 (1958).

8) H. Matsuda, Y. Ayabe, Bull. Chem. Soc. Japan 28, 422 (1955); 29, 134 (1956).

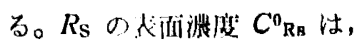

$$
C_{\mathrm{Rg}}^{0}=\frac{1}{D_{\mathrm{Ra}^{1 / 2}}} \int_{0}^{y} \frac{1}{\sqrt{\pi(y-\xi)}}\left[\frac{7}{3} \xi\right]^{-8 / 4} \frac{i_{\mathrm{S}}}{n_{\mathrm{S} q} F} \mathrm{~d} \xi
$$

から求まる。ここで $i_{\mathrm{S}}=i_{0}-i_{1}$ であり，程分字行なうのに式 (1) の関係をむちいると，

$$
\begin{aligned}
& C^{0}{ }_{\mathrm{Rg}}=\left\{\begin{array}{l}
i_{0} \\
\sqrt{\frac{\overline{7}}{3}} \frac{\Gamma(13 / 14)}{\Gamma(3 / 7)} \times 0.0085 F^{2 / 8} t^{1 / 0}
\end{array}\right. \\
& \left.-n_{1} D^{1 / 2} C^{*}+\frac{i_{1}(t)}{F q \lambda}\right\} \frac{1}{n_{\mathrm{S}} D_{\mathrm{RS}}{ }^{1 / 2}}
\end{aligned}
$$

となる。 $t_{\max }$ に打いて $C^{0}{ }_{\mathrm{RB}}=0$ となる場合の加霍流 $\boldsymbol{i}_{0}$ が限界 反応篓流 $i$ にひとしいからこの場合には

\begin{tabular}{|c|c|c|c|}
\hline \multirow[b]{2}{*}{$\lambda \sqrt{t_{\max }}$} & \multirow[b]{2}{*}{ 1）の場合(d) } & \multirow[b]{2}{*}{ ii ）の埸合 ${ }^{b)}$} & \multirow{2}{*}{$\frac{\text { 值 }}{\text { 裳法平均 }}$} \\
\hline & & & \\
\hline 0.0 & 0.000 & 0.000 & 0.000 \\
\hline 0.1 & 0.106 & 0.082 & 0.065 \\
\hline 0.5 & 0.391 & 0.291 & 0.256 \\
\hline 1.0 & 0.579 & 0.449 & 0.400 \\
\hline 2.0 & 0.750 & 0.606 & 0.554 \\
\hline 5.0 & 0.890 & 0.758 & 0.708 \\
\hline 10 & 0.943 & 0.823 & 0.776 \\
\hline 50 & 0.988 & 0.880 & 0.839 \\
\hline$\infty$ & 1.000 & 0.895 & 0.857 \\
\hline
\end{tabular}

$$
i_{l}=635 n_{1} D^{1 / 2} C^{*} m^{2 / 8} t_{\max }^{1 / 6}\left\{1-\Psi\left(\lambda \sqrt{t_{\max }}\right)\right\}
$$

を得る。

表 1 に限界反忘電流を $i_{l}=\left(708 n_{1} D^{1 / 2} C^{*} m^{2 / 8} t_{\max }^{1 / 6}\right) \times P$ で示し た場合の $P$ の值を松田の淪交 ${ }^{8}$ から水めた結果を示す。この関 係から）の場合には常法の最大限哭反忘電流にひとしく，ii） の場合には1）と常法の平均反応電流との間の值を有する。これ は丁度桩散支配の場合と大きさの順序が同じである。

注 $a$ ）松田, 綾部の諭文より司用.

b）松田，蟣部の論文中の表加ら部筑.

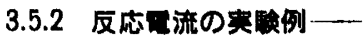

1) $0.01 \mathrm{~N}$ 水化リチゥム中の $0.2 \mathrm{~mol} / l$-デキストロースの反

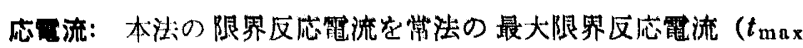
における触流值）と比校した結果，数\%以内の誤差で两者の值は 一致した。これは後㸡電物留が不可逆の場令に期待される関係に 当る*日。その他の挙動む䣘法とほとんど一政した。すなわち， 反応電流の大きさは溶液調製後徐々に增大するるが $23.7^{\circ} \mathrm{C}, h=$ $56.0 \mathrm{~cm}, t_{\max }=2.0_{0} \sec ($ at $-2.1 \mathrm{~V}$ vs. $\mathrm{Hg}$ pool) に拟 $\tau$ 䄪 $21 \mu \mathrm{A}$ の限界雷流を得，水銀溜の高さを $79 \sim 39 \mathrm{~cm}$ の間荿 化しても波高はほよんど変化せず，また溶液の温度を $10^{\circ} \sim 45^{\circ} \mathrm{C}$

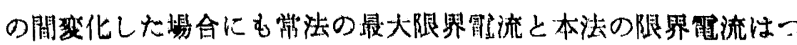

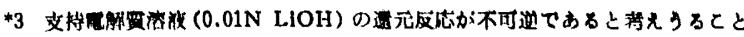

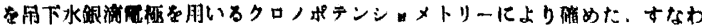

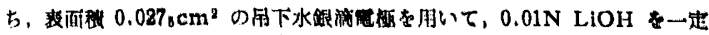

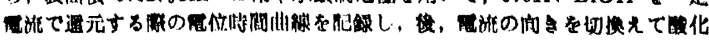

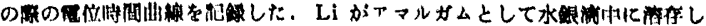

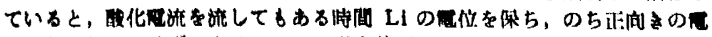

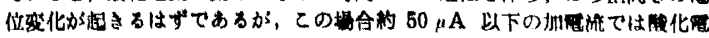

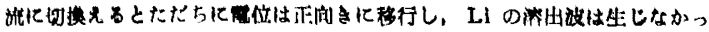

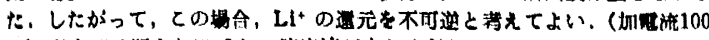

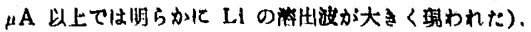

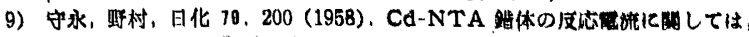
abl Koryta, Collection Capchosiov. Chem. Communs. 24, 3057 (1959) の研紫から方。 
ねにほぼ一致した。

ii）酶酸一酢酸ナトリウム䌅衝溶液中のニトリロトリ酢酸 (NA

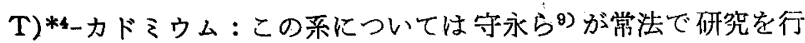
なった。彼は, $\mathrm{CdX}^{-1}+\mathrm{H}^{+} \rightleftarrows \mathrm{Cd}^{2+}+\mathrm{HX}^{-2}$ なる反応により 遊離の $\mathrm{Cd}^{2+}$ が生じ，その還元波が $\mathrm{CdX}^{-1}$ の還元波の前に現わ れることを利用してその解剀速度を求めた。図 4 は本法により測 定した NTA-Cd 系のポーラログラムを常法と比較したもので, 本法においても $\mathrm{Cd}^{2+}, \mathrm{CdX}^{-1}$ の還元による二段波を生じ，第 1 波は常法の第 1 波の最大電流とほぼひとしい限界電流做を有し ている。表 2 には水銀溜の高さと反応電流との関係を示した。こ の表からも常法との顕著な差は認められない。

本例では滴の初期に $\mathrm{CdX}^{-1}$ が $\mathrm{Cd}^{2+}$ とともに還元されるため に電極表面近浐の $\mathrm{CdX}^{-1}$ 濃度は常法よりも幾分小さいことが期 待される。しかし実験結果にはこの影響は大きく現れなかった。

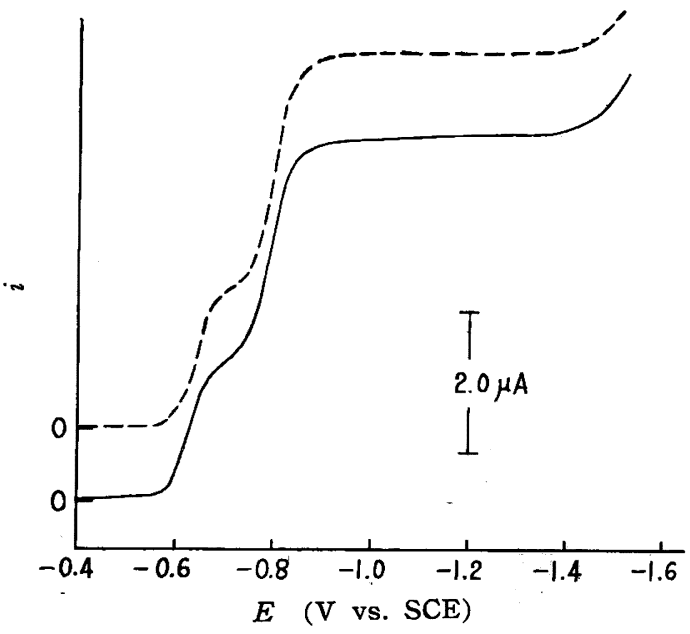

一一：本法， ----: 常法

電解液: $\mathrm{Cd}^{2+} 1.0 \mathrm{~m} \mathrm{~mol} / l, \mathrm{H}_{3} \mathrm{Y} 10.0 \mathrm{~m} \mathrm{~mol} / l$ $0.12 \mathrm{~mol} / l \mathrm{NaOAc}$,

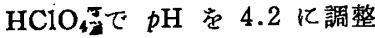

因 4 反応電流のポーラログラム

表 $2 \mathrm{Cd}$ の反応錁流と水銀溜の高さ

$\begin{array}{cccc}\begin{array}{c}\text { 水銀溜高さ } \\ h \begin{array}{c}(\mathrm{cm}) \\ 78.0\end{array}\end{array} & \sqrt{h} & \begin{array}{c}\text { 本法の反忘 } \\ \text { 電流 }(\mu \mathrm{A})\end{array} & \begin{array}{c}\text { 常法の最大反 } \\ \text { 流 }(\mu \mathrm{A})\end{array} \\ 78.8_{4} & 2.0_{0} & 2.0_{7} \\ 55.5 & 7.4_{5} & 1.9_{0} & 2.0_{2} \\ 43.8 & 6.6_{1} & 1.7_{0} & 1.9_{2}\end{array}$

\section{6 触媒電流}

一例としてチタン(IV) の塭酸ヒドロキシルアミンによる触媒波 について検討した ${ }^{10)}$ 。 $\mathrm{Ti}^{4+}$ の還元により生じた $\mathrm{Ti}^{8+}$ は塩酸七 ドロキシルアミンによりふたたび 4 価の $\mathrm{Ti}^{4+}$ に酸化されるため に, 塭酸ヒドロキシルアミン共存下の $\mathrm{Ti}^{4+}$ の還元波がいちじる 乙く高くなることはよく知られている。本法をもちいてこの現象 の検討を行なった結果, 表 3 に示すように; 常法とほとんど同じ ポーラログラムが得られた。したがって常法におけると同様な化 学反応が DME 表面でおきていると考えられる。

\section{7 吸着液}

メチレンブルー (MB) は希薄な場合, 半波電位がその標準酸

*4 NTA $\mathrm{XH}_{3}$ で示す

10) P. Delahay, "Instrumental Analysis" p. 340 (1957).
表 $3 \mathrm{Ti}^{4+}$ の $\mathrm{NH}_{2} \mathrm{OH} \cdot \mathrm{HCl}$ 亿よる触媒野流〕

\begin{tabular}{|c|c|c|c|c|}
\hline $\mathrm{NH}_{2} \mathrm{OH} \cdot \mathrm{HCl}$ & \multicolumn{2}{|c|}{ 電流規正法 } & \multicolumn{2}{|c|}{ 踝位規正法 } \\
\hline $\begin{array}{c}\text { 浱度 } \\
(\mathrm{mol} / \mathrm{l})\end{array}$ & $\begin{array}{c}\text { 半波電位 } \\
(\mathrm{V} \text { vs. SCE })\end{array}$ & 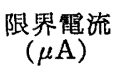 & ( $\mathrm{V} \stackrel{\text { 半波電位 }}{\text { vs. SCE) }}$ & $\begin{array}{c}\text { 限界電流 } \\
(\mu \mathrm{A})\end{array}$ \\
\hline 0 & $-0.26_{2}$ & $2.6_{4}$ & $-0.26_{2}$ & $2.6_{9}$ \\
\hline 0.02 & $-0.26_{5}$ & $4.2_{8}$ & $-0.26_{3}$ & $4.2_{0}$ \\
\hline 0.04 & $-0.27_{3}$ & $5.5_{0}$ & $-0.26_{3}$ & $5.3_{6}$ \\
\hline
\end{tabular}

注 $a)$ 電解液組成: $\mathrm{Ti}^{4+}: 1.0_{0} \mathrm{~m} \mathrm{~mol} / l,(\mathrm{COOH})_{2}: 20^{\circ} \mathrm{C}$ での飽和溶液 $45 \mathrm{ml} / 50 \mathrm{ml} . \mathrm{NH}_{2} \mathrm{OH} \cdot \mathrm{HCl}$ を添加.

化還元電位より $0.1 \mathrm{~V}$ 以上正な電位にある波を生じ，浱度が高く なるとこの変則波の波高はある限度以上には增加せず，これにつ づいて正常な還元波が現われる。この現象は Brdička ${ }^{11)}$ ，Mül.

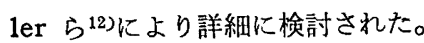

$p \mathrm{H} \mathrm{7.45}$ の第 1 リン酸カリウムーホウ砂緩衝溶液中での MB の 挙動を本法と常法とについて比較検討した結果, 本法においても 同様に異常に正な電位に変則波を生じ，つぎに正常な還元波が現 われ，さらに負な電位において接触水素波を生じた。変則波の限 界電流よりもわずかに大きい加電流で電解した場合の DME 電位 時間曲線は，はじめ負な電位にありただちに異常に正な変則波の 電位まで移行する（このさい正常波の電位で一度止ることはな い)。その後しばらくしてふたたび急に正常波の電位へと負向き に移行する。このことは Brdička のように還元体の電極表面へ の吸着を仮定すると説明できる。すなわち，滴の初期においては $\mathrm{MB}$ ともに後放電物質の䢬元がおきるが，䑁移時間 $(\tau)$ 以後 はMB の還元のみに加電流 $i_{0}$ が消費される。それ以後 $\mathrm{MB}$ の表 面濃度は急速に増加するが，還元型の片は生成後ただちに吸着さ れると仮定すると電流が流れても溶液中の還元型の表面浱度はき わめて小さい值にたもたれている。したがってネルンスト式か ら DME 電位は異常に正な值を示す。ところがさらに電流が流 れて電極面が完全に MB の還元型で被われたのちは電解された 量だけ MB の還元型の溶液中の表面浱度が增加するために急㳒 正常波の電位へと負向きに変化する。

このように考えると $t_{\mathrm{max}}$ において電位が正常波の電位へもど る場合の加電流 $i_{0}$ は近似的に（ $\tau \ll t_{\max }$ とすると $)$

$$
i_{0} t_{\mathrm{max}}=0.0085 \mathrm{~m}^{2 / 8} t_{\text {max }}^{2 / 3} z \times 2 F
$$

を满足する。ここで $z$ は最大吸着の場合の $\mathrm{mol} / \mathrm{cm}^{2}$ 。式 (7) の関係を满足する $i_{0}$ は Brđička によると常法での変則波の平 均限界電流にひとしい。表 4 は実驗的にこの関係が成立すること を示している。式 (7) から $z$ を求めると $z=1.6_{4} \times 10^{-10} \mathrm{~mol} /$ $\mathrm{cm}^{2}$ となり, Brdička の $1.62 \times 10^{-10} \mathrm{~mol} / \mathrm{cm}^{2}$ とよく一致し た。また変則波の波高は本法でも水銀溜の高さに比例した。

\section{表 4 変則波の限界電流}

$\begin{array}{ccc}\underset{\mathrm{MB} \text { 浀度 }}{(\mathrm{m} \mathrm{mol} / l)} & \text { 常法平均電流 } & \begin{array}{c}\text { 本 法 } \\ (\mu \mathrm{A})\end{array} \\ 0.10 & 0.20_{0} & 0.20_{0} \\ 0.20 & 0.21_{0} & 0.20_{5} \\ 0.40 & 0.19_{5} & 0.19_{8}\end{array}$

終りに本研究を行なうに当り終始御愁䉆なる御指溥を睗りまし た京都大学石橋雅義名兴教授, 藤永太一郎教授に梁甚の謝意を表 します。

11) R. Brdička, Z. Elehtrochem. 48, 278 (1942); Collection Czechoslov. Chem. Communs, 12, 212 (1947).

12) O. H. Müller, Trans. Electrochem. Soc. 87,441 (1945). 